ORIGINAL ARTICLE

\title{
The Effect of Sapodilla Leaves (Achras Zapota) Infusum towards Mice (Mus Muculus) Diarrheal Activity Induced by Oleum Ricini
}

\author{
Glabela Christiana Pandango ${ }^{1}$, Ramadhani R. $B^{1 *}$., Irfiansyah Irwadi ${ }^{1}$ \\ ${ }^{1}$ Faculty of Medicine Universitas Airlangga - RSUD Dr. Soetomo, Surabaya, Indonesia
}

\author{
A R T I C L E I N F O \\ Article history: \\ Received 4 April 2018 \\ Received in revised form 18 April \\ 2018 \\ Accepted 20 April 2018 \\ Available online 30 April 2018

\section{Keywords:} \\ Diarrhea \\ Increased bowel's motility \\ Increased bowel's secretion \\ Sapodilla leaves' infusum \\ Diarrheal activities .

\section{*) Corresponding author:} \\ ramadhaninani@gmail.com
}

\begin{abstract}
A B S T R A C T
Introduction: Diarrhea is a significant health problem, especially in countries with low income, even can cause death. Treatment for diarrhea has been done both pharmacologically (including the usage of herbal remedies) and non-pharmacologically. Decoction of the sapodilla's leaves is often used to treat diarrhea, but no studies directly demonstrates the effects of sapodilla's leaves' decoction towards living creatures. The purpose of this study was to determine the effect of Sapodilla leaves' (Achras zapota) infusum towards diarrheal activity of mice (Mus musculus) which can be seen through the onset and frequency of diarrhea, and the consistency and quantity / weight of feces. Methods: 30 mice were divided into five groups. Negative controls (group I) were administered with oleum Ricini, positive controls (group II) were administered with oleum Ricini and Loperamide $\mathrm{HCl}$ after half-an hour, and group III, IV, and V, were administered with oleum Ricini and sapodilla leaves' (Achras zapota) infusum (with the concentration of $5 \mathrm{~g} \%, 10 \mathrm{~g} \%$, and $20 \mathrm{~g} \%$ ) after half-an hour. Then, all groups observed for 3 hours for their diarrheal activity (diarrheal onset, frequency, fecal consistency, and fecal weights). Results: Statistic analysis by Kruskal-Wallis method showed significant differences of diarrheal activities among the five groups $(\mathrm{p}=0.023)$. Whilst, analysis by Mann-Whitney method showed significant differences between group I and II ( $\mathrm{p}=0.04)$, group I and III ( $\mathrm{p}$ $=0.012)$, and group I and IV ( $\mathrm{p}=0.006)$.

Conclusions: Based on the result showed sapodilla leaves' (Achras zapota) infusum could reduce diarrheal activity of mice (Mus musculus).
\end{abstract}

\section{Introduction}

Diarrhea is a major health problem, especially in lowincome countries. In many cases, diarrhea even causes death.(1) Diarrhea is a bowel movement of fluid that occurs more than three times each day or in frequency more often than normal people.(2) One of the processes in the body that causes diarrhea is a change in motility of the gastrointestinal tract.(3)

Diarrhea treatment can be done with pharmacological and non-pharmacological therapy. While non-pharmacologic therapies focus on the replacement of body fluids lost due to diarrhea, pharmacological therapies focus on suppression of intestinal peristalsis.

Sapodilla or Sawo is a group of plants belonging to the Sapotaceae and grows considerably in Indonesia and has been used as a medicinal plant. Sapodilla boiled leaf water has even been used by the community as a medicine for diarrhea, although there is no further research to investigate its effects directly on living things.(4) This turned out to be in accordance with previous study which investigated the active ingredients in the Manilla sapodilla leaves. Studies shows that leaves contained saponin and flavonoids.(5) Saponins

Biomolecular and Health Science Journal. All rights reserved. 
can increase intestinal absorption while flavonoids can reduce peristalsis and secretions in the gut. $(6,7)$

This study aims to determine the effect of infusion of sapodilla manila leaves (Achras zapota) to the decrease of diarrhea activity in mice (Mus musculus). Parameters that measured were the time of diarrhea / onset of diarrhea, frequency of diarrhea, consistency and number / weight of feces.

\section{Methods}

This laboratory experimental research was designed using randomized post test controlled design method. The research was conducted on June 15, 2013 at Pharmacology Laboratory of Airlangga University using adult male mice, age about 3 months, weight 20 gram, and physical health condition. Mice used were divided into five treatment groups by random sampling. The amount of replication was determined by using Freeder formula and found 30 research subjects with 6 mice as negative control group, 6 mice as positive control group, and the other three as treatment group. Diarrhea activity data retrieval was done by placing the mice in individual container for observation.

Prior to implementation, this research proposal has been approved by the Health Ethics Committee of Medical Faculty, Universitas Airlangga Surabaya, due to the use of mice (Mus musculus) as experimental animals. This research was conducted in three stages, namely pretreatment phase, treatment stage, and data retrieval stage. At the pre-treatment stage, a sapodilla leaf infusion (Achras zapota) was made by mixing the dried brown leaves powder with $100 \mathrm{ml}$ of distillate water on a measuring cup then heated and held at a temperature of $90^{\circ} \mathrm{C}$ over a pot containing water for 15 minutes, after that it filtered using flannel.

Before treatment, the mice were acclimatized for one week with laboratory conditions for self-habituation during the study. At the treatment stage, the animals were divided into five groups at random, Group I, II, III, IV and V. Group I was a group with Ricini oleum alone; group II (positive control) was a group of mice given Loperamide $\mathrm{HCl} 2 \mathrm{ml} / \mathrm{kg} \mathrm{BW}$, then after one hour was given orally $0.75 \mathrm{ml}$ of Ricini oleum; group III (first treatment group) was a group of mice treated with $5 \%$ leaf of sawo manila (Achras zapota) extract, and after one hour was given orally $0.75 \mathrm{ml}$ of Ricini oleum; group IV (second treatment group) was a group of mice treated with leaf extract of sawo manila (Achras zapota) $10 \%$, then after one hour given by oral $0.75 \mathrm{ml}$ of Ricini oleum; group V (third treatment group) was a group of mice given leaf extract of sawo manila (Achras zapota) $20 \%$, then after one hour given by oral $0.75 \mathrm{ml}$ of Ricini oleum. The data retrieval stage about diarrheal activities is done by observation, which includes time of diarrhea, frequency of diarrhea, consistency and number / weight of feces and duration of diarrhea. The response of each mouse was observed at the 30th, 60th, 90th, 120th, 150th, 180th, 210th, 240th, 300th, 360th minutes after giving the castor oil.(8)

\section{Results}

Table 1. Mice Diarrheal Activity

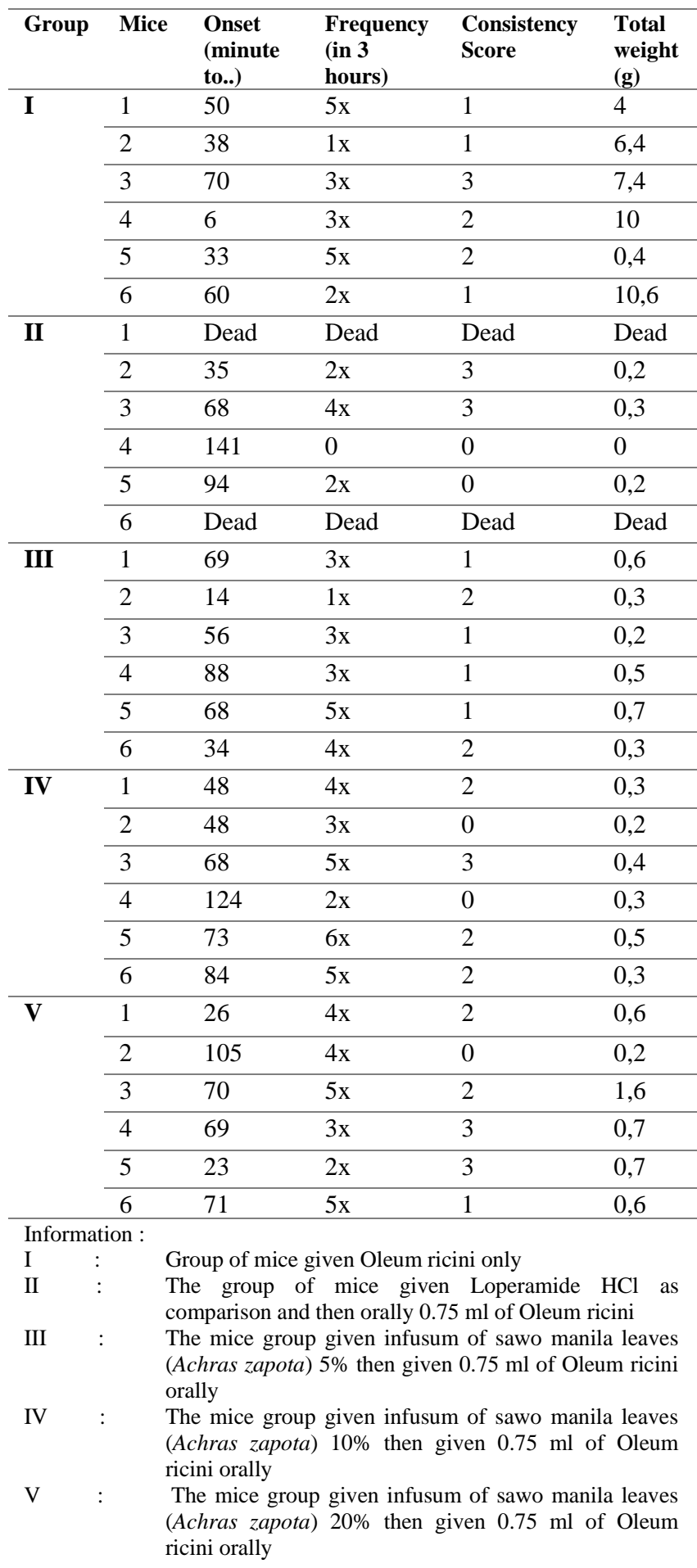


If described in the graphical from, the table will look like this.
Table 2. Mice Diarrhea Activity after scoring

\begin{tabular}{|c|c|c|c|c|c|c|}
\hline Group & Mice & Onset & $\begin{array}{l}\text { Fre- } \\
\text { quency }\end{array}$ & $\begin{array}{l}\text { Consis- } \\
\text { tency }\end{array}$ & $\begin{array}{l}\text { Total } \\
\text { weight }\end{array}$ & $\begin{array}{l}\text { Total } \\
\text { score }\end{array}$ \\
\hline \multirow[t]{6}{*}{ I } & 1 & 2 & 2 & 1 & 3 & 8 \\
\hline & 2 & 3 & 0 & 1 & 3 & 7 \\
\hline & 3 & 2 & 1 & 3 & 3 & 9 \\
\hline & 4 & 3 & 1 & 2 & 3 & 9 \\
\hline & 5 & 3 & 2 & 2 & 0 & 7 \\
\hline & 6 & 2 & 1 & 1 & 3 & 7 \\
\hline \multirow[t]{6}{*}{ II } & 1 & Dead & Dead & Dead & Dead & Dead \\
\hline & 2 & 3 & 1 & 3 & 0 & 7 \\
\hline & 3 & 2 & 2 & 3 & 0 & 7 \\
\hline & 4 & 0 & 0 & 0 & 0 & 0 \\
\hline & 5 & 1 & 1 & 0 & 0 & 2 \\
\hline & 6 & Dead & Dead & Dead & Dead & Dead \\
\hline \multirow[t]{6}{*}{ III } & 1 & 2 & 1 & 2 & 1 & 6 \\
\hline & 2 & 3 & 0 & 0 & 0 & 3 \\
\hline & 3 & 2 & 1 & 3 & 0 & 6 \\
\hline & 4 & 1 & 1 & 0 & 1 & 3 \\
\hline & 5 & 2 & 2 & 2 & 1 & 7 \\
\hline & 6 & 3 & 2 & 2 & 0 & 7 \\
\hline \multirow[t]{6}{*}{ IV } & 1 & 2 & 2 & 1 & 0 & 5 \\
\hline & 2 & 2 & 1 & 2 & 0 & 5 \\
\hline & 3 & 2 & 2 & 1 & 0 & 5 \\
\hline & 4 & 0 & 1 & 1 & 0 & 2 \\
\hline & 5 & 2 & 3 & 1 & 1 & 7 \\
\hline & 6 & 1 & 2 & 2 & 0 & 5 \\
\hline \multirow[t]{6}{*}{$\mathbf{V}$} & 1 & 3 & 2 & 2 & 1 & 8 \\
\hline & 2 & 1 & 2 & 0 & 0 & 3 \\
\hline & 3 & 2 & 2 & 2 & 3 & 9 \\
\hline & 4 & 2 & 1 & 3 & 1 & 7 \\
\hline & 5 & 3 & 1 & 3 & 1 & 8 \\
\hline & 6 & 2 & 2 & 1 & 1 & 6 \\
\hline \multicolumn{7}{|c|}{ Information : } \\
\hline \multicolumn{2}{|c|}{ Onset score } & $\begin{array}{l}0: \\
1: \\
2: \\
3:\end{array}$ & $\begin{array}{l}\text { inutes to }> \\
\text { inutes to } 7 \\
\text { inutes to } 4 \\
\text { inutes to }\end{array}$ & $\begin{array}{l}05 \\
-105 \\
-75 \\
45\end{array}$ & & \\
\hline \multicolumn{2}{|c|}{ Frequency score } & $\begin{array}{l}0: \\
1: \\
2: \\
3:\end{array}$ & $\begin{array}{l}-5 \mathrm{x} \text { in } 6 \mathrm{~h} \\
-10 \mathrm{x} \text { in } 6 \mathrm{~h} \\
1-15 \mathrm{x} \text { in } 6 \\
15 \mathrm{x} \text { in } 6 \mathrm{~h}\end{array}$ & $\begin{array}{l}\text { Irs } \\
\text { urs } \\
\text { ours } \\
\text { rs }\end{array}$ & & \\
\hline Consi & ency score & \multicolumn{5}{|c|}{$\begin{array}{l}2: \text { Slimy / watery form a mass of feces } \\
3: \text { Slimy / watery not forming a mass of } \\
\text { feces }\end{array}$} \\
\hline \multicolumn{2}{|c|}{ Weight score total } & $\begin{array}{l}0: \\
1: \\
2: \\
3:\end{array}$ & $\begin{array}{l}-0,4 \text { gram } \\
5-0,9 \text { gran } \\
-1,4 \text { gram } \\
1,5 \text { gram }\end{array}$ & & & \\
\hline
\end{tabular}

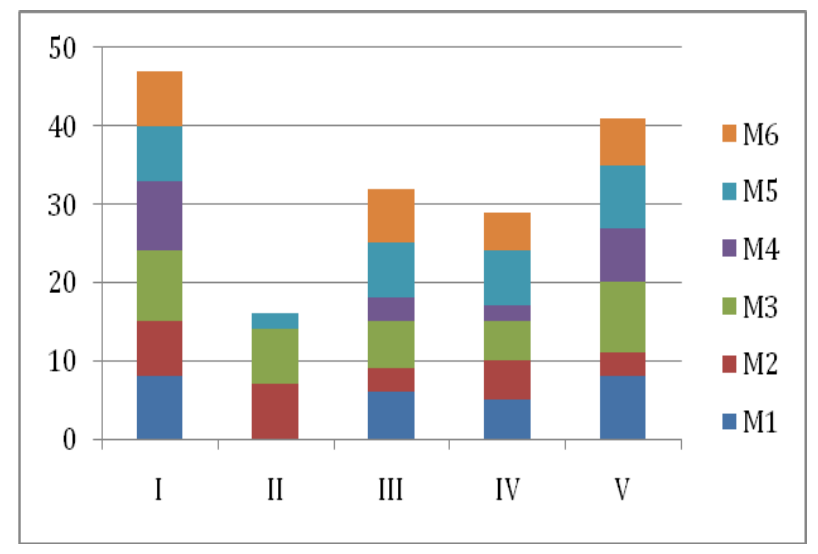

Figure 1 Graph of Total Diarrhea Activity Score in Five Mice Groups

Anti-diarrhea effect of sapodilla leaf infusion was tested using 5 groups of mice, each group consists of 6 mice. Group I as negative control was given aquadest, group II as positive control using Loperamid $\mathrm{HCl} 2 \mathrm{mg} /$ $\mathrm{kg} \mathrm{BW}$, and the treatment groups III, IV and $\mathrm{V}$ were given $5 \%, 10 \%$, and $20 \%$ leaf extract of sawo manila (Achras zapota). An hour later each mouse was given the oil as much as $0.5 \mathrm{ml} /$ mice. The diarrheal activities of the mice in each group could be seen in Table 1, which were later converted into scores and presented in Table 2. The highest diarrheal score was achieved by the mice in the negative control group (aquadest), while the total diarrheal activites' scores in the positive control group (loperamide) and treatment groups (leaf extract) were presented to be lower.

Based on Kruskall Wallis test, the significance value between groups is 0,023 . This means that there are significant differences between groups. To know which groups had significant differences, the next test done was Mann-Whitney. From the results of the test analysis, significant differences were found between groups I and II, I and III, and I and IV. Two of the three treatment groups (Group III and IV) showed significant differences in reducing the diarrheal activity of the mice. In those two groups, mice were given $5 \%$ and $10 \%$ of Acras zapota's infusum.

\section{Discussion}

In this study there were significant differences between group I and II, where negative control group only given Oleum ricini and positive control given Loperamid $\mathrm{HCl}$ $2 \mathrm{mg} / \mathrm{kg} \mathrm{BW}$ before being given Oleum ricini. The 
positive control group differed significantly from the negative control group in the weight of the stool. The stool's weight in group II was 0-0,4 grams on average. This is consistent with the pharmacological theory of Loperamid that Loperamid can reduce peristaltic and fluid secretion in the gastrointestinal tract, resulting in longer transit time in the gastrointestinal tract and increased absorption of fluid and electrolytes in the gastrointestinal tract. Loperamid is also able to protect mice from oleum ricini-induced diarrhea.

Significant differences were obtained when compared between groups I and III as well as between groups I and IV, which is a negative control group treated only with Oleum ricini with a group treated with 5\% and $10 \%$ sapodilla leaves infusum (Achras zapota) and then treated with Oleum ricini. This is in accordance with the empirical experience of the people who use a bowl of chopped sapodilla leaf and boiled in two glasses of clean water for 15 minutes and drink 3 times a day (4). These results are also supported by investigation of the chemical content of Achras zapota leaves which have been proven to contain Saponin and Flavonoids that have been proven to have antidiarrheal effects.(9) Flavonoids have been shown to weaken the contraction of ileum in guinea pig induced by some spasmogen, and inhibit the transit of feces in the small intestine. $(10,11)$

Whereas, there was no significant difference between group I and $\mathrm{V}$, that is between negative control group which only given Oleum ricini and sawo manila leaves infusion (Achras zapota) 20\%. Mice in group V had early onset of diarhea (started to present with diarrhea in the first 0-75 $\mathrm{min}$ ) and soft consistency of the stool (produced watery and mucoid stool). The same result was also shown in the use of morphine as an antidiarrheal drug. Morphine, when used in low doses can decrease the intestinal tone causing constipation. Meanwhile, when administered in higher doses will cause spasmogenic effects and cause diarrhea.(12) This means that the optimum dose of inhibition of diarrheal activity from the infusion of the sapodilla leaves (Achras zapota) is between $5-10 \%$.

A significant difference was also not obtained when comparing groups II and III, groups II and IV, and groups II and $\mathrm{V}$, which is a positive control group given Loperamide $\mathrm{HCl} 2 \mathrm{mg} / \mathrm{kg} \mathrm{BW}$ before being given Oleum ricini and the groups given sawo manila leaves infusion (Achras zapota) 5\%, 10\%, and 20\% then given Oleum ricini. This is due to the workings of Flavonoids and Saponins, the active ingredients in the sapodilla leaves, which are not the same as Loperamide's way of reducing peristaltic or weakening intestinal contractions.(10) Meaning, at these doses, the sawo manila leaves infusion have already gave the antidiarrheal effect not significantly different from Loperamide $\mathrm{HCl}$ with a dose of $2 \mathrm{mg} / \mathrm{kg} \mathrm{BW}$ and which means it can be used as a substitute for Loperamide.
In this study there is no significant difference between the three concentrations of infusum. This suggests that the use of these concentrations makes little difference in reducing diarrheal activity between one and the other. However, when compared with the group of mice given $5 \%$ and $10 \%$ of the sapodilla leaves infusion, the mice group given $20 \%$ of the sapodilla leaves infusion had a lower antidiarrheal effect and showed no significance when compared to the negative control group.

\section{Conclusion}

The treatment of sawo manila leaves infusum with concentration $5 \mathrm{~g} \%$ and $10 \mathrm{~g} \%$ can significantly reduce the activity of mice (Mus musculus) diarrhea induced by Oleum ricini, while the sawo manila leaves infusum with a concentration $20 \mathrm{~g} \%$ cannot significantly reduce the activity of mice (Mus musculus) diarrhea with similar treatment.

\section{Conflict of Interest}

The author stated there is no conflict of interest.

\section{References}

1. WHO. Diarrhoeal diseases. Geneva: World Health Organization, 2009.

2. WHO. Diarrhoea. Geneva: World Health Orgasization, 2012.

3. Bailen. Diarrhea and Malabsorption 2007.

4. Sentana A. Health Secret of Kiwifruit. Jakarta: PT Elex Media Komputindo; 2010.

5. Sugati, Johnny. Inventaris Tanaman Obat Indonesia (I). Jakarta: Departeman Kesehatan RI, Badan Penelitian Pengembangan Kesehatan; 1991.

6. Tam KI. 2010. Available from: http://dspace.uta.edu/bitstream/handle/10106/5142/Tam_ut a_2502D_10761.pdf?sequence $=1$

7. Carlo G. 1993. Available from: http://www.ncbi.nlm.nih.gov/pubmed/7908974

8. Adnyana IK, al e. Efek Ekstrak Daun Jambu Biji Daging Buah Putih Dan Jambu Biji Daging Buah Merah Sebagai Antidiare. Acta Pharmaceutica Indonesia. 2004;XXIX(1):18-20

9. Longanga, Otshudi A, Vercruysse A, Foriers A. Contribution to the ethnobotanical, phytochemical and pharmacological studies of traditionally used medicinal plants in the treatment of dysentery and diarrhea in Lomela area, Democratic Republic of Congo (DRC). Journal of Ethnopharmacology. 2000;71:411-23.

10. Macander PJ. Flavonoids affect acetylcholine, prostaglandin E and antigenmediated smooth muscle contraction. Progress in Clinical Biological Research. 1986;231:489-92.

11. Viswanathan S, Thirugnana SP, Bapha JS. Flavonoid induced delay in the small intestinal transit. Possible mechanism of action. Archives Internationales Pharmacodynamie et de Therapie 1984;270:151-7.

12. Branson KR, Gross ME. Opioid Agonists and Antagonists. Veterinary Pharmacology and Therapeutics, 8th ed. Adam HR, editor. Ames: Iowa State University Press; 2001. 
